\title{
Metasomatic replacement of diopside by enstatite: A mechanism to convert a lherzolite protolith to orthopyroxene-rich harzburgite
}

\author{
J.M. Koornneef ${ }^{1,2}$, G.R. Davies ${ }^{1}$, Z. Vukmanovic ${ }^{1}$, I.K. Nikogosian ${ }^{1}$, E.C. Fulmer ${ }^{1}$ \\ ${ }^{1}$ Department of Petrology, Vrije Universiteit Amsterdam, The Netherlands \\ ${ }^{2}$ Now at Institute of Isotope Geochemistry and Mineral Resources, ETH Zürich, Switzerland
}

Sub-continental lithospheric mantle (SCLM) is thought to represent the residue after extensive partial melting. Studies of peridotites transported to the surface by volcanic eruptions show, however, that the SCLM below some cratons (e.g. Kaapvaal) are too rich in orthopyroxene (opx) to be residua of partial melting (Boyd, 1989). Silica-rich metasomatism of an initially depleted mantle has been proposed to explain the higher than expected opx mode, but the nature of this enrichment process is poorly understood. Here we report the occurrence of metasomatic textures in mantle xenoliths from Labait and Elodoi volcanoes, northern Tanzania, which record replacement of clinopyroxene (cpx) by opx. We infer that the texture observed in these xenoliths represents a snapshot of the process causing the conversion of lherzolitic protoliths to opxrich harzburgites. A detailed combined petrology and in situ major- and trace element and $\mathrm{Sr}-\mathrm{Nd}$ isotope study of the minerals forming the texture is presented on a sample from Labait.

\section{Labait and Elodoi}

The xenolith described in detail in this work was collected from Labait volcano (S4 $34^{\prime} 4.5^{\prime \prime} \mathrm{E} 35^{\circ} 25^{\prime}$ 49.5"), an olivine melilitite cone located at the northeastern edge of the Tanzanian craton adjacent to the Eastern African Rift. Labait erupted during the pleistocene and transported numerous extremely fresh xenoliths, varying in composition from dunites (70\%), to harzburgites $(10 \%)$, lherzolites $(10 \%)$, wherlites $(5 \%)$ pyroxenites $(3 \%)$ and glimmerites $(2 \%)$. Elodoi volcano forms a cone built of flows and tuffs south of Lake Natron (S2 ${ }^{\circ} 45^{\prime} 39.1$ ' E36 ${ }^{\circ}$ 01'35.4'). Peridotite xenoliths from Elodoi generally show higher degrees of metasomatism than Labait and range in composition from dunites $(43 \%)$ to harzburgites $(5 \%)$, lherzolites (35\%), wherlites (11\%) websterite $(3 \%)$ and glimmerites (3\%). Many Elodoi samples also contain amphibole. Four samples contain diopsidic cpx cores with opx overgrowth reaction textures.

Re-Os depletion ages for mantle xenoliths from Labait yield minimum melt extraction ages of up to $2.8 \mathrm{Ga}$ (Chesley et al., 1999). The cratonic mantle presently exist to depths of at least $150 \mathrm{~km}$ beneath Labait and the peridotites define a $50 \mathrm{~mW} / \mathrm{m}^{2}$ geotherm, which is significantly hotter than the $41 \mathrm{~mW} / \mathrm{m}^{2}$ geotherm defined by Kaapvaal low temperature garnet perdotites. A general correlation was found to exist between bulk composition of the xenoliths and depth of equilibration, with more fertile peridotites occurring at depths greater than 140 km (Lee and Rudnick, 1999). Dawson (1999) recognised several metasomatic events that resulted in modification of the initial residual composition.

\section{Petrography}

The Labait peridotite xenolith discussed here (AT65) is a small $(5 \times 4 \times 3 \mathrm{~cm})$ coarse grained spinel lherzolite that contains 'primary' clinopyroxene that is rimmed or completely replaced by secondary orthopyroxene. Olivine forms $75 \%$ of the rock, opx $12 \%$, cpx $10 \%$ spinel $2 \%$ and glass and phlogopite $<1 \%$. Silicate glass is found along $10 \%$ of grain boundaries and in small melt pockets.

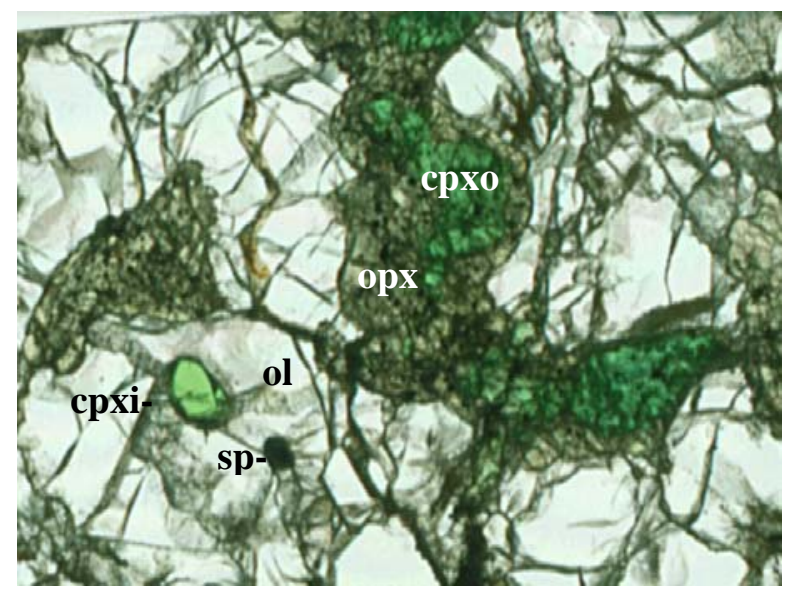

Figure 1. Photomicrograph of spinel lherzolite AT65 from Labait. Width of field $1 \mathrm{~cm}$. Cpx is replaced by opx (cpxo) that contains numerous spinel and melt inclusions. Cpx included in olivine (cpxi) is free of the opx reaction corona.

Olivine $(2-8 \mathrm{~mm})$ forms an in-equigranular texture with irregular grain boundaries. Large grains show undulose extinction, kink banding and cracks. Spinel and cpx occur as round mineral inclusions in olivine. Opx (1-2 $\mathrm{mm})$ is found both as a primary and secondary phase. Primary opx is clear and represents $20 \%$ of the total opx mode. The secondary metasomatic opx is 'cloudy' due to the occurrence of numerous fluid/melt and spinel inclusions. Grains are anhedral with extremely irregular grain boundaries. The secondary opx replaces cpx partially or completely (Fig $1)$. The boundary between the opx and cpx is irregular but sharp (Fig. 2).

Cpx (0.5-1 mm) occurs as clear and rounded inclusions in olivine (cpxi) and as anhedral lobate grains partially replaced by opx (cpxo). The cpx surrounded by opx contains many fluid and spinel inclusions. Primary 
deep-red round spinel grains $(0.2-0.5 \mathrm{~mm})$ have 'spongy' reaction rims when in contact with glass. Spinel inclusions in the opx and cpx are $<10 \mu \mathrm{m}$ and do not have reaction rims. Melt pockets $(\sim 1 \mathrm{~mm})$ contain grains of sp, cpx, phlogopite and ilmenite.

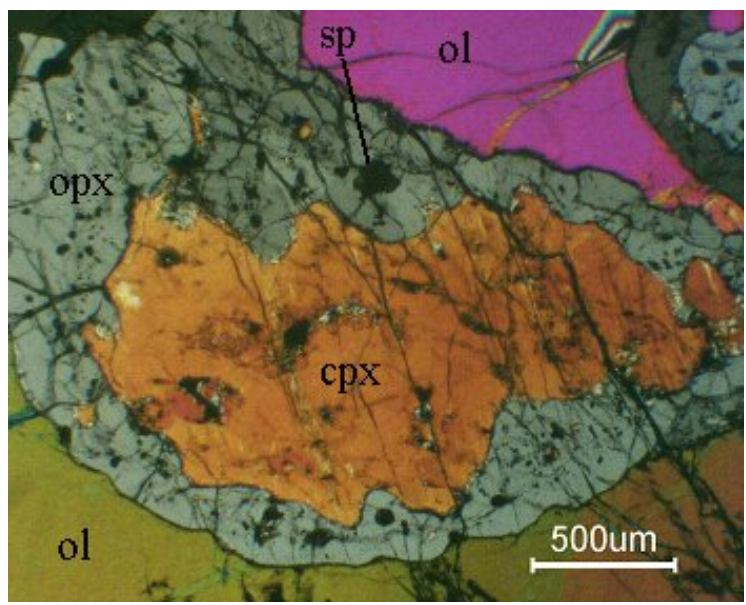

Figure 2. Photomicrograph of metasomatic texture in AT65 (crossed nicols).

\section{Mineral chemistry}

Olivine is homogeneous with $\mathrm{Mg} \#$ of 90.7. Primary enstatite is homogeneous for both major and trace elements. It has relatively high $\mathrm{Al}_{2} \mathrm{O}_{3}(2.3 \%)$ and $\mathrm{Cr}_{2} \mathrm{O}_{3}(0.6 \%)$ typical for spinel facies opx. In contrast, the secondary opx is much more variable in composition compared to opx in other Labait xenoliths (especially for $\mathrm{Al}_{2} \mathrm{O}_{3}, \mathrm{Cr}_{2} \mathrm{O}_{3}$ and $\mathrm{TiO}_{2}$ ). The opx is relatively rich in $\mathrm{Al}_{2} \mathrm{O}_{3}(1.8-2.6 \%)$ and $\mathrm{Cr}_{2} \mathrm{O}_{3}(0.42-$ $0.73 \%)$ and has low $\mathrm{SiO}_{2}(55.4-56.2 \%)$ and $\mathrm{CaO}$ $(0.56-0.8 \%)$. Primary opx has low trace element contents and is depleted in LREE $\left(\mathrm{La} / \mathrm{Yb}_{\mathrm{N}} \sim 0.1\right.$; Fig 3) whereas the secondary orthopyroxene has highly variable trace element concentrations that range from LREE enriched to depleted $\left(\mathrm{La} / \mathrm{Yb}_{\mathrm{N}} \quad 17\right.$ to 0.2 respectively; Fig. 3). Hf and $\mathrm{Zr}$ are high in these LREE enriched metasomatic opx and $(\mathrm{Nb} / \mathrm{La})_{\mathrm{N}}>1$. Cpx surrounded by opx is Cr-diopside compositionally similar to other cpx at Labait with minor core to rim zonation in $\mathrm{CaO}$ and $\mathrm{Na}_{2} \mathrm{O}\left(\mathrm{Na}_{2} \mathrm{O}\right.$ increases from 1.7 to $2.0 \mathrm{wt}$; $\mathrm{CaO}$ decreases from $20.0 \%$ to $18.5 \%$ ). Cpx are LREE enriched and have convex-upward REE patterns with maxima at $\operatorname{Pr}$ or $\mathrm{Nd}\left(\mathrm{La} / \mathrm{Nd}_{\mathrm{N}}<1, \mathrm{Nd} / \mathrm{Lu}_{\mathrm{N}}>>1\right)$ and a gradual decrease of MREE and HREE to $\mathrm{Lu}_{\mathrm{N}} \sim 1$. Round blebs of chrome spinel are primary and have relatively low $\mathrm{Cr} \#(57)$ and $\mathrm{TiO}_{2}(0.5-1.3 \%)$ compared to spinels included in the metasomatic opx (Cr\# 69, $\mathrm{TiO}_{2} 1.3-1.8 \%$ ), and spinel in melt pocket assemblages (Cr\# 67, $\mathrm{TiO}_{2} 1.4$ to $2.1 \%$ ).

\section{Interstitial glass and melt inclusions}

Glass occurring along grain boundaries and in melt pockets is variable in composition. Glasses show a restricted range of $\mathrm{SiO}_{2}(\sim 47-55 \%)$ and low concentrations of $\mathrm{MnO}, \mathrm{Cr}_{2} \mathrm{O}_{3}$ and $\mathrm{Na}_{2} \mathrm{O}$ but high concentrations of $\mathrm{Al}_{2} \mathrm{O}_{3}, \mathrm{MgO}(14.1 \%), \mathrm{FeO}(13.4 \%)$ and $\mathrm{K}_{2} \mathrm{O}$. Melt inclusions analyzed in olivine, opx and spinel show a similar range in composition to the interstitial glasses. Glass included in cpx has slightly higher $\mathrm{Al}_{2} \mathrm{O}_{3}$ but lower $\mathrm{FeO}$. All glasses have extremely low $\mathrm{N}_{2} \mathrm{O} / \mathrm{K}_{2} \mathrm{O}(0.01-0.6)$.

\section{Sr-Nd isotope data}

Clinopyroxene inclusions in olivine and clinopyroxene surrounded by opx were hand-picked. Both cpx fractions have relatively radiogenic $\mathrm{Sr}$ and unradiogenic $\mathrm{Nd}(0.7048 ; 0.5124)$ indicating a time integrated LREE history. Opx (representing a mixture of primary and secondary opx) has less radiogenic $\mathrm{Sr}$ and more radiogenic $\mathrm{Nd}(0.7045,0.5126)$ suggesting a mixed origin from the protolith and recent volcanism.

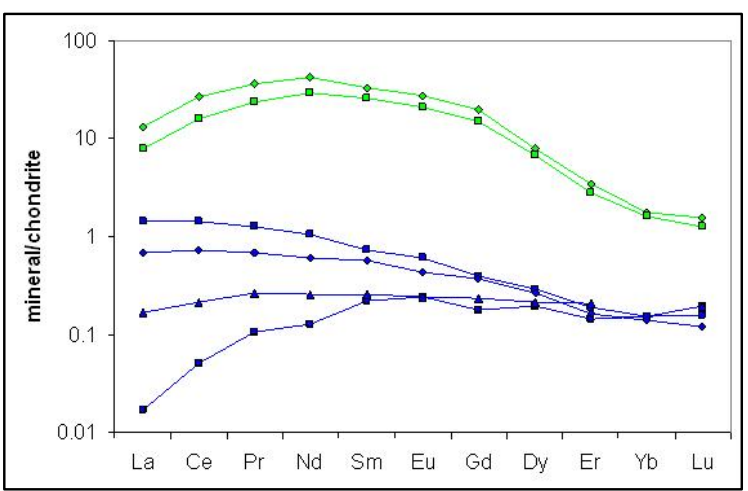

Figure 3. Chondrite normalized REE plot for clinopyroxene (green) and orthopyroxenes (blue) in AT65. Primary orthopyroxene has a LREE depleted signature (squares) whereas metasomatic opx show large variation in LREE content.

\section{Discussion}

The reaction coronas and the variable chemistry of opx record a disequilibrium texture. Furthermore, the reaction is incomplete (Fig. 1) so that the samples record a snapshot of an ongoing process that must have formed immediately prior to xenolith eruption. Due to the chemical disequilibrium, determining the pressure and temperature at which the reaction took place requires assumptions. Assuming that primary opx and cpx cores are in equilibrium the Brey and Kohler (1990) 2 pyroxene thermometer yields $\mathrm{T}$ of $983^{\circ} \mathrm{C}$ at a preset $\mathrm{P}$ of $2.5 \mathrm{GPa}$. Assuming equilibration of the rims of the opx and cpx in the metasomatic texture yields a much higher temperature of $1134{ }^{\circ} \mathrm{C}$ at $2.5 \mathrm{GPa}$. This suggests a relatively high temperature of the metasomatic fluid.

Elevated $\mathrm{Al}_{2} \mathrm{O}_{3}$ and $\mathrm{Cr}_{2} \mathrm{O}_{3}$ in the metasomatic opx can be explained by inherited characteristics of the primary cpx. Extreme LILE and LREE enrichment seen in the secondary orthopyroxene, together with the prominent $\mathrm{Zr}$ - Hf anomaly indicates that the fluid was enriched in these elements. Absence of hydrous phases and formation of opx rather than amphibole suggests that the fluid must have had low $\mathrm{H}_{2} \mathrm{O}$ activity or that the reaction took place outside the stability field of amphibole (Dawson 1989).

The similar range in composition of interstitial glasses and melt inclusions (often close to mineral rims) 
suggests they belong to the same infiltration event. The extremely low $\mathrm{N}_{2} \mathrm{O} / \mathrm{K}_{2} \mathrm{O}$ in all glasses analyzed precludes any link with the sodic-rich host olivine melilitite $\left(\mathrm{Na}_{2} \mathrm{O} 1.87 \%\right.$ Dawson, 1997). The glass composition suggests that the metasomatic medium was a K-alkaline silicate melt low in $\mathrm{CaO}$ and $\mathrm{Na}_{2} \mathrm{O}$.

Mineral Sr-Nd isotope systematics record clear isotopic disequilibrium between cpx and opx. To obtain the unradiogenic $\mathrm{Nd}$ in the cpx, LREE enrichment must have occurred in the Proterozoic $\left(\mathrm{T}_{\mathrm{Ma}} \sim 2.0 \mathrm{Ga}\right)$. The 'primary' cpx is therefore found to have a metasomatic origin itself, indicating that at least two metasomatic events occurred during the history of the Tanzanian craton, a conclusion compatible with previous studies (e.g. Dawson, 1999). Due to the marked isotopic disequilibrium between cpx and opx, and the high $\mathrm{Sm} / \mathrm{Nd}$ of the metasomatic opx, it is not possible to use the Sr-Nd data of the opx to directly infer the time of the second metasomatism. The isotopic composition and inferred trace element composition of the metasomatic fluids inferred from the trace element enriched opx are, however, indistinguishable to recent magmas erupted in N. Tanzania (Paslick et al. 1995). Together with the observed disequilibrium, this suggests that the metasomatism occurred shortly before the eruption that transported the xenolith to the surface.

The compositions of spinels from AT65 clearly support the proposal that the xenolith has been affected by at least two magmatic episodes. Primary bleb shaped spinels have low $\mathrm{Al}_{2} \mathrm{O}_{3}$ and $\mathrm{TiO}_{2}$ comparable to spinels formed in subduction related magmas suggesting that at least part of the earlier history of the xenolith occurred in an arc environment (Kamenetskey et al., 2001). In contrast, spinels associated with the opx forming reaction have higher $\mathrm{Al}_{2} \mathrm{O}_{3}$ and $\mathrm{TiO}_{2}$ more comparable to spinels from within plate magmas. Spinels in the glass pockets have comparable or slightly higher $\mathrm{TiO}_{2}$ suggesting formation from the Krich alkaline silicate melt.

A similar reaction texture to that from Labait and Elodoi has been reported by Dawson (1987) from Lashaine, Tanzania. Dawson ascribes the texture to 'flushing' of the lherzolite by an anhydrous $\mathrm{CO}_{2}$-rich vapour that would be converted by the reaction to a magnesium carbonatite. This study found no petrographic evidence of carbonate in the melt pockets or melt inclusions so that we cannot support $\mathrm{CO}_{2}$-rich vapour as the process responsible for the formation of these metasomatic textures. Instead we propose that the conversion of clinopyroxene to orthopyroxene took place via a reaction: $\mathrm{Cr}$-diopside + (opx saturated) $\mathrm{Si}$ rich fluid $\rightarrow$ enstatite $+\mathrm{Cr}$-spinel minus $\mathrm{Ca}$ and $\mathrm{Na}$ (cpx saturated fluid).

Kelemen et al. (1992) proposed that harzburgite can be produced by reaction between a lherzolite and migrating basaltic melt. In this model fluids formed at high pressure become olivine saturated at lower pressures, dissolving pyroxenes. Dunites will be the reaction product; the liquids will become saturated in opx. This opx saturated melt will dissolve cpx, causing the liquid to become cpx saturated. Migration of this fluid to higher levels will cause formation of pyroxenite. The initial fluid in this reaction is a small degree eclogitic melt that formed from partial melting of a subducted oceanic crust. Rudnick et al. (1994) proposed a similar process to explain the opx enrichment in Kaapvaal peridotites.

The opx forming metasomatic texture in AT65 is a snapshot of the very recent conversion of a lherzolite to a harzburgite. The melt involved is clearly a trace element enriched melt that has a low LREE/HFSE ratio characteristic of highly trace element enriched within plate magmatism. This melt is in strong contrast to that proposed by previous workers. The nature of the opx formation at Labait, Elodoi and by inference Lashaine, indicates that opx enrichment of the SCLM is an ongoing process beneath Tanzania that does not require a subduction related magma. Further work is required to establish if the opx-rich peridotites that characterise Kaapvaal and Siberian SCLM are also derived from within plate magmatism.

\section{References}

Boyd, F.R. (1989) Compositional distinction between oceanic and cratonic lithosphere. Earth and Planetary Science Letters, 96, 15-26.

Brey, G.P. and Kohler, T. (1990) Geothermobarometry in four-phase lherzolites II. New thermobarometers, and practical assessment of existing thermobarometers. Journal of Petrology, 31, 1353-1378.

Chesley J.T., et al. (1999) Re-Os systematics of mantle xenoliths from the East African Rift: Age, structure, and history of the Tanzanian craton. Geochimica et Cosmochimica Acta, Vol. 63 no. 7/8, 1203-1217

Dawson J.B. (1987) Metasomatized harzburgites in kimberlite and alkaline magmas: Enriched restites and "flushed" lherzolites. In Mantle Metasomatism (eds. M.A.Menzies and C.J. Hawkesworth), Academic Press, London, 125-144.

Dawson J.B. (1999) Metasomatism and Melting in Spinel Peridotite Xenoliths from Labait, Tanzania. In Proceedings $7^{\text {th }}$ International Kimberlite Conference, 164-173.

Kamenetsky V.S. et al. (2001) Factors controlling chemistry of magmatic spinel: an empirical study of associated olivine, $\mathrm{Cr}$ spinel and melt inclusions in primitive rocks. Journal of Petrology, 42, 655-671.

Kelemen, P.B. et al. (1992) Formation of harzburgite by pervasive melt-rock reaction in the upper mantle, Nature, 358, 635-641.

Lee C.-T. and Rudnick R.L. (1999) Compositionally Stratified Cratonic Lithosphere: Petrology and Geochemistry of Peridotite Xenoliths from the Labait Volcano, Tanzania. In Proc. $7^{\text {th }}$ Internat. Kimberlite Conf. 503-521.

Paslick C.R., et al. (1995) Enrichment of the continental lithosphere by OIB melts: Isotopic evidence from the volcanic province of northern Tanzania. Earth and Planetary Science Letters, Vol 130, 109-126.

Rudnick R. L., et al. (1994) Northern Tanzanian peridotite xenoliths: a comparison with Kaapvaal peridotites and inferences on metasomatic interactions. Proceedings $5^{\text {th }}$ International. Kimberlite Conference, 336-353. 